\title{
KONTRIBUSI TERNAK SAPI SEBAGAI ALAT TRANSPORTASI OLEH PETANI KEBUN KELAPA DI KECAMATAN JAILOLO KABUPATEN HALMAHERA BARAT
}

\author{
Albert Panawa $^{*}$ J. Lainawa ${ }^{* *}$; G.D. Lenzun ${ }^{* *}$, F. H. Elly ${ }^{* *}$ \\ Fakultas Peternakan Universitas Sam Ratulangi Manado 95115
}

\begin{abstract}
ABSTRAK
Ternak sapi di Kecamatan Jailolo pada tahun 2013 berjumlah 3.410 ekor, seluruhnya dikembangkan secara tradisional. Ternak sapi di daerah ini dimanfaatkan oleh petani sebagai sarana transportasi kebun. Pemanfaatan tersebut merupakan budaya petani setempat, dan akses jalan ke kebun belum tersedia untuk transportasi kendaraan bermotor. Ternak sapi sebagai alat transportasi berperan penting dan dapat diandalkan oleh petani untuk mengangkut hasil kebun. Permasalahannya sejauhmana pemanfaatan ternak sapi sebagai alat transportasi terhadap petani peternak dan berapa besar kontribusi pendapatan petani peternak dalam pemanfaatan sarana transportasi gerobak sapi. Tujuan penelitian untuk mengetahui pemanfaatan ternak sapi sebagai alat transportasi dalam mengangkut hasil kebun kelapa dan untuk mengetahui kontribusi pendapatan petani peternak dalam pemanfaatan sarana trasnportasi gerobak sapi. Metode penelitian yang digunakan adalah metode survei, sumber data yang diperoleh adalah data primer dan data sekunder. Penentuan desa sampel dilakukan secara purposive sampling. Responden ditentukan secara simple random sampling dengan jumlah 30 responden. Kesimpulannya transportasi gerobak memberikan kontribusi dilihat dari waktu kerja ternak sapi sebesar 1.284 jam per periode produksi kelapa untuk mengangkut hasil kebun kelapa, pisang, dan pala. Sarana transportasi gerobak memberikan kontribusi pendapatan sebesar Rp. 23.095.000 atau 8.21\% dari keseluruhan pendapatan petani per periode produksi kelapa.
\end{abstract}

\section{Kata kunci : Sarana transportasi, Ternak sapi, Petani kelapa, Kontribusi pendapatan, Jailolo Halmahera Barat}

\begin{abstract}
CONTRIBUTION OF CATTLE AS THE TRANSPORTATION INSTRUMENT OF FARMERS ON COCONUT PLANTATION AT JAILOLO DISTRICT, WEST HALMAHERA REGENCY. Total of cattle at Jailolo district in year of 2013 were 3,410 heads and bred traditionally by household farmers. Cattle at Jailolo district were used by household farmer as transportation instrument around

*Alumni Fakultas Peternakan

**Jurusan Sosial Ekonomi
\end{abstract}


plantation areas. The problem was that cattle contribution on farmer income as transportation instrument had not been evaluated. The objective of this study was to evaluate cattle contribution on farmer income as transportation instrument in coconut plantation. Research was done using survey method. Data were found from household farmers and found from related offices. Samples of villages were taken using purposive sampling. Household farmers were defined using simple random sampling involving 30 samples. Results showed that cattle as transportation instrument contributed work time period of 1,284 hours per period of plantation including coconut, banana and nutmeg production. Transportation instrument involving cattle contributed household income of Rp. 23,095,000 or 8,21 percents of the total household income per production period of coconut plantation.

\section{Key words: Transportation instrument, Cattle, Household farmers, Income contribution, Jailolo district, West Halmahera Regency.}

\section{PENDAHULUAN}

Kabupaten Halmahera Barat, saat ini telah dikembangkan ternak sapi bali, sapi peranakan Madura dan sapi PO dengan jumlah yang relatif sedikit. Usaha pemeliharaan ternak sapi sebagai usaha sampingan atau bersifat sebagai tabungan hidup yang sewaktu-waktu dapat dijual saat dibutuhkan. Ternak sapi dimanfaatkan sebagai tenaga kerja dalam usaha tani untuk mengolah tanah dan mengangkut hasil pertanian (Dinas Pertanian dan Ketahanan Pangan Daerah Provinsi Maluku Utara, 2011).

Gerobak adalah sarana transportasi tradisional di Kabupaten Halmahera Barat yang merupakan warisan para leluhur yang ramah lingkungan, aman serta mudah untuk dikendarai. Gerobak di Kabupaten Halmahera Barat biasanya ditarik oleh seekor ternak sapi jantan dan dikendarai oleh orang dewasa baik pria maupun wanita. Gerobak juga dikendarai oleh anak-anak yang dipergunakan untuk mengangkut hasilhasil pertanian dan perkebunan. Awalnya bagi kebanyakan masyarakat di Kabupaten Halmahera Barat, keberadaan ternak sapi dan gerobak merupakan tingkat kekayaan seseorang tetapi perkembangan saat ini ternak sapi tidak lagi menjadi ukuran tingkat kekayaan seseorang karena dengan adanya program Dinas Pertanian Kabupaten Halmahera Barat serta ditunjang oleh Dinas Pertanian Propinsi Maluku Utara, melalui 
pengadaan ternak sapi dan gerobak sehingga ternak sapi serta gerobak sudah tersebar sampai di hampir setiap Kecamatan di Wilayah Kabupaten Halmahera Barat (Dinas Pertanian Kabupaten Halmahera Barat, 2013 ).

Hasil prasurvey menunjukkan bahwa khusus di daerah Kecamatan Jailolo Kabupaten Halmahera Barat jumlah total populasi ternak sapi sebanyak 3.410 ekor. Ternak sapi seluruhnya dikembangkan secara tradisional. Ternak sapi tersebut dipelihara dengan sistem digembalakan di bawah pohon kelapa, pada waktu pagi ternak sapi dituntun oleh petani untuk mencari makan, dan diikat pada tempat tertentu. Petani tidak memberikan vaksinasi serta pengobatan bagi ternak sapi (BP3K, 2011). Pemanfaatan ternak sapi sebagian dijadikan sebagai tenaga kerja pertanian sekaligus tenaga kerja transportasi.

Ternak sapi di Kecamatan Jailolo dimanfaatkan oleh petani sebagai sarana transportasi kebun. Hal ini disebabkan karena akses jalan di kebun belum tersedia untuk transportasi kendaraan bermotor. Pemanfaatan ternak sapi sebagai transportasi merupakan budaya dari petani setempat. Permasalahannya sejauhmana pemanfaatan ternak sapi sebagai tenaga kerja belum diketahui. Permasalahan lainnya adalah berapa besar kontribusi pendapatan dari tenaga kerja ternak sapi terhadap total pendapatan petani juga belum diketahui. Tujuan penelitian ini adalah untuk mengetahui sejauhmana pemanfaatan ternak sapi sebagai alat transportasi gerobak dan kontribusi tenaga kerja ternak sapi sebagai alat transportasi gerobak terhadap pendapatan petani.

\section{MATERI DAN METODE PENELITIAN}

Penelitian ini telah dilaksanakan di Kecamatan Jailolo Kabupaten Halmahera Barat. Metode penelitian yang digunakan adalah metode survei. Menurut Kerlinger (2004), metode survey adalah penyelidikan untuk memperoleh fakta-fakta dan gejalagejala yang ada dan informasi faktual dari responden dengan menggunakan kuesioner. Data penelitian ini diperoleh dari dua sumber yaitu data primer dan data sekunder. Data primer diperoleh dari wawancara langsung dengan responden, 
sedangkan data sekunder diperoleh dari lembaga atau instansi- instasi terkait yang dalam hal ini, Dinas Pertanian dan BP3K.

Penentuan desa sampel dilakukan secara purposive sampling, yaitu secara sengaja dengan tujuan menyajikan atau menggambarkan beberapa sifat populasi. Penggunaan teknik ini senantiasa didasarkan pada pengatahuan tentang ciri-ciri tertentu yang terdapat dalam populasi (Suyatna dan Antara, 2004). Penentuan desa sampel dengan pertimbangan desa-desa tersebut memiliki jumlah populasi ternak sapi terbanyak serta terdapat usaha perkebunan kelapa. Desa-desa tersebut diantaranya Desa Hoku-Hoku kie, Desa Tedeng dan Desa Akediri. Berdasarkan tiga desa terpilih diperoleh populasi petani yang memiliki kriteria : (a) Petani peternak sapi yang memiliki kebun kelapa; (b) Ternak yang sudah bisa dipekerjakan (menarik gerobak); (c) Peternak yang memiliki lebih dari 2 ekor sapi. Berdasarkan populasi petani sesuai kriteria tersebut ditentukan responden secara simple random sampling. Nama desa dan populasi petani serta jumlah responden dapat dilihat pada Tabel 1.

Definisi variabel penelitian dan pengukurannya yaitu (1) Biaya produksi adalah seluruh biaya yang dikeluarkan dalam usaha ternak sapi penarik gerobak, terdiri dari biaya tetap dan biaya tidak tetap yang dihitung dalam satuan $\mathrm{Rp} /$ periode produksi kelapa; (2) Biaya tetap adalah biaya yang tidak berubah dalam periode produksi, terdiri dari biaya gerobak dan biaya tali. Biaya tidak tetap adalah biaya yang berubah-rubah dalam periode produksi, terdiri dari biaya pengobatan dan biaya pemeliharaan ternak sapi penarik gerobak yang dihitung dalam satuan Rp/periode produksi kelapa; (3) Penerimaan adalah uang yang diterima dari penyewaan gerobak dalam mengangkut hasil kebun kelapa, pisang, dan pala yang hitung dalam satuan Rp/periode produksi kelapa; (4) Pendapatan adalah penerimaan setelah dikurangi biaya produksi gerobak yang dihitung dalam satuan Rp/periode produksi kelapa; (5) Pendapatan total petani adalah jumlah pendapatan dari usaha tani, luar usaha tani dan transportasi gerobak yang dihitung dalam satuan Rp/produksi periode kelapa; (6) Pendapatan usaha tani adalah penerimaan dari hasil kebun kelapa, pisang dan pala. Pendapatan luar usaha tani yang terdiri dari penerimaan ojek, sopir, kepala desa, pensiun dan pegawai negeri sipil yang dihitung dalam satuan Rp/periode produksi 
kelapa; (7) Persentase pendapatan transportasi gerobak adalah penerimaan dari hasil penyewaan gerobak setelah dibagi dengan total pendapatan petani yang dihitung dalam satuan Rp/periode produksi kelapa.

Tujuan pertama dalam penelitian ini, yaitu untuk mengetahui pemanfaatan ternak sapi sebagai alat transportasi dalam mengangkut hasil kebun kelapa. Tujuan ini dijawab dengan analisis deskriptif. Menurut Suryana (2010) deskriptif bertujuan untuk membuat deskripsi secara sistematis, faktual dan akurat mengenai fakta-fakta, dan sifat populasi daerah tertentu.

Tujuan kedua adalah untuk mengetahui kontribusi pendapatan petani dalam pemanfaatan sarana transportasi gerobak sapi. Tujuan ini dijawab dengan mengunakan analisis kontribusi menurut Soekartawai (1995), seperti terlihat pada persamaan :

$$
K=\frac{Y_{i}}{Y_{t}} x 100 \%
$$

Keterangan :

$\mathrm{K}$ : Persentase kontribusi pendapatan.

Yi : Pendapatan dari usaha transportasi ternak.

Yt : Pendapatan petani peternak, yaitu pendapatan usahatani dan luar usahatani serta pendapatan transportasi gerobak.

\section{HASIL DAN PEMBAHASAN}

Lahan dan iklim di Kecamatan Jailolo memiliki sifat saling mempengaruhi dan saling berkorelasi terhadap $\mathrm{pH}$ maupun kesuburan tanah. Tanah adalah media tumbuh bagi tumbuhan sehingga kesuburan tanah atau lahan itu perlu dijaga dan dipelihara. Kecamatan Jailolo memiliki tipe iklim panas, pada bulan Juli sampai bulan Oktober adalah musim kemarau, bulan November sampai Februari musim hujan dengan curah hujan kisaran 2000-3000 mm/Tahun, serta musim pancaroba pada bulan Maret sampai Juli. 
Topografi atau bentuk tanah di kecamatan Jailolo tergolong tanah datar karena dilihat dari jumlah desa di Kecamatan Jailolo dari 29 Desa, 21 Desa memiliki tanah datar, sementara 8 desa memiiliki tanah berbukit-bukit.

Jumlah penduduk di Kecamatan Jailolo sebanyak 29.433 Jiwa terdiri atas 18.995 jiwa laki- laki atau 64,40 \% dan wanita sebanyak 10.478 jiwa atau 35,59\% dengan jumlah kepala keluarga sebanyak 6.705. Tingkat pendidikan di wilayah ini sangat beragam mulai dari Sekolah dasar sampai perguruan tinggi. Mulai dari tingkat pendidikan yang belum sekolah atau putus sekolah berjumlah 15.000 atau 50,96\%, dan Sekolah Dasar SD 5.000 atau 16,98\%, serta Sekolah Lanjutan Tingkat Pertama 5.500atau 18,68\%, kemudian Tingkat Sekolah Lanjutan Atas 2.433 atau 8,26\%, dan sisanya Perguruan Tinggi 1500 atau 5,09\%. Tingkat pengembangan sumber daya manusia di Kecamatan Jailolo perlu ditingkatkan dengan memberikan kesempatan seluas-luasnya kepada masyarakat untuk mengenyam pendidikan yang lebih baik.

Penduduk Kecamatan Jailolo memiliki mata pencaharian yang bervariasi, mulai dari petani yang terdiri dari 21.000 atau 71,34\% dan non tani 6.000 atau $20,38 \%$, serta yang sisanya bergerak dibidang lain adalah 2.433 atau 8,26\% dari jumlah Penduduk yang ada di Kecamatan Jailolo yaitu 29.433. Terlihat persentase mata pencarian diatas mununjukan bahwa mayoritas mata pencarian Penduduk Kecamatan Jailolo adalah petani.Sehingga diharapkan kedepan akan memberikan lapangan kerja seluas-luasnya bagi penduduk yang ada di Kecamatan Jailolo begitu pula pada sektor perdagangan dan sektor penunjang kegiatan Agribisnis lainnya.

Lahan merupakan suatu tempat terbuka di permukaan bumi yang dimanfaatkan oleh manusia, sementara luas dan penggunaan lahan di Kecamatan Jailolo bervariasi, yaitu seperti penggunaan lahan untuk kebun sawah dan ladang 2.517 Ha, serta padang rumput $1.256 \mathrm{Ha}$, kemudian tambak $25 \mathrm{Ha}$, dan kolam $56 \mathrm{Ha}$, dan untuk penggunaan lahan hutan $716 \mathrm{Ha}$, serta $75 \mathrm{Ha}$, dan pekarangan $995 \mathrm{Ha}$.

Pendidikan adalah faktor yang sangat penting dalam suatu kegiatan usaha karena pendidikan seseorang dapat mempengaruhi penyerapan inovasi dan teknologi baru untuk meningkatkan usaha peternakan. Semakin tinggi tingkat pendidikan peternak maka semakin tinggi kualitas sumberdaya manusia, yang pada gilirannya 
semakin tinggi pula produktivitas kerja yang dilakukannya. Oleh karena itu, tingkat pendidikan yang semakin tinggi diharapkan kinerja usaha peternakan semakin berkembang (Syafaat et al, 1995). Hal ini sependapat dengan Soekartawi (1986) menyatakan bahwa tingkat pendidikan peternak cenderung mempengaruhi cara berfikir dan tingkat penerimaan mereka terhadap inovasi dan teknologi baru. Berdasarkan data penelitian umur responden cukup bervariasi yang terdiri dari umur 26 tahun sampai dengan umur 73 tahun. Menurut Kairupan (2011), usia 15-55 Tahun adalah umur yang produktif. Hasil penelitian menunjukkan bahwa tingkat pendidikan responden di Kecamatan Jailolo terdiri dari tingkat SD 10 responden, SMP 12 responden, SMA 5 responden, kemudian PGSD 2 responden, dan S1 1 responden. Data ini menunjukkan tingkat pendidikan responden di Kecamatan Jailolo masih di kategori rendah. Menurut Ahmadi (2003) tingkat pendidikan yang rendah menyebabkan seseorang kurang mempunyai ketrampilan tertentu yang diperlukan didalam kehidupannya. Keterbatasan pendidikan yang dimiliki menyebabkan keterbatasan kemampuan untuk mengelola pekerjaannya.

Hasil penelitian menunjukkan bahwa status kepemilikan ternak sapi dan gerobak adalah 100 persen milik petani peternak itu sendiri. Petani peternak yang memiliki kebun kelapa semuanya mempunyai ternak sapi dan gerobak, sehingga pada waktu panen kebun kelapa, pisang, dan pala, petani menggunakan ternak sapi dan gerobak untuk mengangkut hasil kebun tersebut. Pemanfaatan ternak sapi sebagai alat transportasi gerobak sangat menunjang petani peternak dalam mengangkut hasil usaha pertanian maupun perkebunan. Hal ini disebabkan karena sarana jalan di kebun tidak tersedia untuk kendaraan bermotor dalam mengangkut produksi perkebunan. Penggunaan ternak sapi dan gerobak juga merupakan budaya dari masyarakat di daerah penelitian.

Hasil penelitian ini menunjukan bahwa petani mengeluarkan biaya pakan ternak sapi penarik gerobak/ekor Rp. 90.000 dalam satu periode produksi kelapa dengan harga pakan Rp 100/kg. Biaya pakan ini berbeda dengan penelitian Bamualim et al (2004), bahwa biaya pakan dalam penelitian mereka relatif lebih besar, oleh karena pemberian pakan sapi sebanyak 30kg/ekor/hari. Jenis pakan atau hijauan yang 
diberikan adalah rumput alam, dan rumput gajah serta sedikit daun jagung. Ternak sapi juga diberikan $1 \mathrm{~kg}$ konsentrat yang terdiri atas sagu dan dedak (Bamualim et al, 2004). Ternak sapi di Kecamatan Jailolo mengkonsumsi pakan dalam satu hari berkisar $10 \mathrm{~kg}$. Pemberian pakan pada pagi hari sebanyak satu ikat rumput dengan berat $5 \mathrm{~kg}$, demikian juga pada sore hari. Jenis pakan yang diberikan yaitu dalam bahasa lokal rumput "Jela-Jela" (Axonophus Compresus), rumput "Jela-Jela LakiLaki" (Brachiaria Humidicola), serta Leguminosa yaitu Siratro" dan Rumput Pokalgrup". Biaya pakan yang dikeluarkan petani per periode produksi kelapa sebanyak Rp 2.700.000 atau rata-rata $\mathrm{Rp} 90.000$ per responden per periode produksi. Biaya pakan yang dikeluarkan oleh petani masih dikategorikan rendah. Pemeliharaan ternak sapi di Kecamatan Jailolo masih bersifat tradisional sehingga rumput yang diberikan masih rumput alam yang tumbuh di bawah pohon kelapa. Menurut Abidin dan Simanjutak (1997), di negara kita pemberian makanan pada ternak belum diperhatikan. Umumnya peternak hanya memberikan hijauan dengan cara digembalakan di lapangan. Kualitas rumput sangat rendah, karena jarang terdapat pemeliharaan rumput-rumputan hijauan ternak secara khusus untuk makanan ternaknya.

Data penelitian menunjukkan bahwa waktu petani atau responden memindakan ternak sapi pada pagi hari selama 1 jam dan sore hari 1 jam dengan jumlah ternak sapi yang bervariasi yaitu 6 ekor sampai 12 ekor. Perhitungan biaya tenaga kerja dalam penelitian ini dihitung khusus ternak sapi yang menarik gerobak yaitu 1 ekor ternak sapi per responden. Curahan waktu yang dikeluarkan untuk memindahkan ternak sapi penarik gerobak rata-rata pada pagi hari 10 menit dan sore hari 10 menit, sedangkan waktu memberi minum ternak sapi penarik gerobak yaitu 10 menit dalam satu kali memberi minum, kemudian ternak sapi dalam satu minggu diberi minum dua kali. Biaya tenaga kerja untuk memindahkan ternak sapi penarik gerobak dalam satu hari/ekor yaitu Rp 3.125, kemudian biaya yang dikeluarkan oleh patani untuk memberi minum ternak sapi dalam 1 minggu Rp. 3.125. Keseluruhan biaya yang di keluarkan untuk tenaga kerja dalam satu periode produksi kelapa yaitu Rp. 318.750, dengan biaya rata-rata Rp. 10.625/ periode produksi kelapa. 
Kesehatan ternak merupakan hal yang perlu diperhatikan dalam usaha peternakan sebab ternak yang sehat dapat meningkatkan produksi kerja yang lebih baik. Hasil penelitian di Kecamatan Jailolo belum sepenuhnya memperhatikan tentang kesehatan ternak dan apabila ada ternak yang sakit petani hanya mengobati dengan menggunakan minyak tanah, yodium, vitamin serta antibiotika. Biaya pengobatan ternak sapi berkisar Rp. 5.000-10.000 dalam tiga bulan. Tindakan vaksinasi tidak pernah dilakukan oleh petani.

Biaya gerobak yang dikeluarkan oleh petani relatif, karena tahun pembelian tidak sama sehingga harga dari gerobakpun berbeda-beda. Tahun 1998 harga gerobak Rp. 500.000 sementara Tahun 2002 harganya Rp. 750.000 dan Tahun 2008 harganya adalah Rp 1.000.000. Tahun 2014 harga gerobak Rp. 2500.000 sampai dengan Rp. 3.000.000. Jumlah biaya yang dikeluarkan oleh petani untuk membeli gerobak Rp. 20.000.000 dengan rata-rata biaya $\mathrm{Rp}$. 666.666.7.

Hasil penelitian menunjukkan rata-rata pengunaan tali sapi penarik gerobak sebanyak 8 meter per ekor dengan harga satu meter tali sapi Rp. 3.500. Biaya yang di keluarkan petani untuk membeli tali sapi yaitu Rp. 28.000 per ekor, biaya keseluruhan responden membeli tali sapi berkisar Rp. 840.000, dengan rata-rata biaya tali sapi Rp. 28.000.

Kapasitas gerobak mengangkut kopra sesuai hasil penelitian berkisar 3-4 karung dengan bobot satu karung kopra 9-100 kg. Tata cara penyewaan transportasi ternak sapi di daerah penelitian yaitu mulai dari mengangkut kelapa, dikumpulkan disatu tempat, kemudian mengangkut kopra yang sudah diisi dalam karung ke dekat jalan raya. Harga penyewaan untuk satu karung kopra Rp. 25.000. Pendapatan transportasi gerobak dari keseluruhan responden dalam mengangkut hasil kebun kelapa yaitu Rp. 18.550.000 atau rata-rata dalam satu periode produksi kelapa (tiga bulan) berjumlah Rp. 618.333.33.

Penyewaan ternak sapi mengangkut hasil kebun pisang untuk satu gerobak atau satu kali tarik Rp. 15.000. Pendapatan transportasi gerobak mengangkut pisang Rp. 4.500.000 atau rata-rata Rp. 150.000 dalam satu periode produksi kelapa. 
Hasil panen kebun pala berkisar enam bulan satu kali panen sehingga pendapatan transportasi gerobak sapi disesuaikan dengan produksi kebun pala. Kapasitas transportasi gerobak mengangkut pala yakni 10 karung sampai 15 karung. Penyewaan transportasi gerobak untuk mengangkut hasil kebun pala yaitu Rp. 15.000 satu gerobak atau satu kali tarik. Pendapatan transportasi gerobak mengangkut hasil kebun pala adalah Rp. 45.000, atau rata-rata Rp. 1.500 dalam satu periode produksi kelapa.

Pendapatan petani di Kecamatan Jailolo cukup bervariasi, yang bersumber dari kebun kelapa, pala, dan pisang. Hasil penelitian menunjukan bahwa pendapatan hasil panen kebun kelapa dari keseluruhan petani sebagai responden yaitu Rp.142.800.000 dengan rata-rata dalam periode produksi kelapa yaitu Rp. 4.760.000.

Masa panen kebun pala yaitu enam bulan satu kali panen sedangkan tenaga kerja untuk panen pala digunakan tenaga kerja keluarga dan total pendapatan responden Rp.5.800.000 atau rata-rata Rp. 193.333.33. per periode produksi kelapa.

Pisang termasuk sumber pendapatan yang cukup menopang hidup petani di Kecamatan Jailolo. Hasil panen pisang dalam satu minggu satu kali panen dengan total pendapatan dalam periode produksi kelapa Rp.46.080.000 atau rata-rata Rp.1.536.000 per petani per peiode produksi kelapa. Pendapatan usaha tani dapat dilihat pada Tabel 2.

Data pada Tabel 2 menunjukkan bahwa pendapatan petani di Kecamatan Jailolo yang terbesar adalah pendapatan yang bersumber dari usaha kebun kelapa dengan jumlah 142.800 .000 atau 73.35 persen. Pendapatan yang lain yaitu kebun pisang Rp. 46.080 .000 atau 23.66 persen. Pendapatan dari kebun pala yaitu Rp. 5.800.000 atau 2.97 persen.

Pendapatan responden diluar usaha tani yaitu seperti ojek, sopir, pensiun, PNS dan Kepala Desa. Pendapatan luar usaha tani dari keseluruhan petani yaitu Rp. 63.500.000 atau rata-rata sebesar Rp. 2.116.667 dalam satu periode produksi kelapa.

Kontribusi adalah keikutsertaan, keterlibatan, melibatkan diri maupun sumbangan.Ternak adalah hewan yang dipelihara dengan tujuan untuk mengambil hasil ternak baik yang berupa daging, susu maupun tenaganya. Penelitian ini yaitu 
untuk mengetahui seberapa besar kontribusi ternak sapi sebagai alat transportasi pada petani di Kecamatan Jailolo Kabupaten Halmahera Barat. Persentase kontribusi pendapatan transportasi gerobak dihitung berdasarkan pendapatan dari transportasi gerobak dibagi dengan pendapatan petani dan dikalikan dengan $100 \%$. Kontribusi transportasi gerobak dapat dilihat Tabel 3.

Data pada Tabel 3 menunjukkan kontribusi pendapatan transportasi gerobak Rp. 23.095.000 atau 8.21 persen. Berbeda dengan penelitian Luas (2007) yang menunjukkan bahwa pendapatan tenaga kerja ternak sapi di Kecamatan Langowan Timur Kabupaten Minahasa menyumbang 19.04 persen terhadap pendapatan petani. Hasil penelitian Luas (2007) menunjukkan ternak sapi mengangkut hasil perkebunan dan membajak sawah. Hasil penelitian Olii (2013) menunjukkan kontribusi usaha ternak sapi terhadap pendapatan rumahtangga petani di Kecamatan Kalawat Kabupaten Minahasa Untara sebesar 15,92 persen. Kontribusi transportasi gerobak dapat dilihat pada Gambar 1.

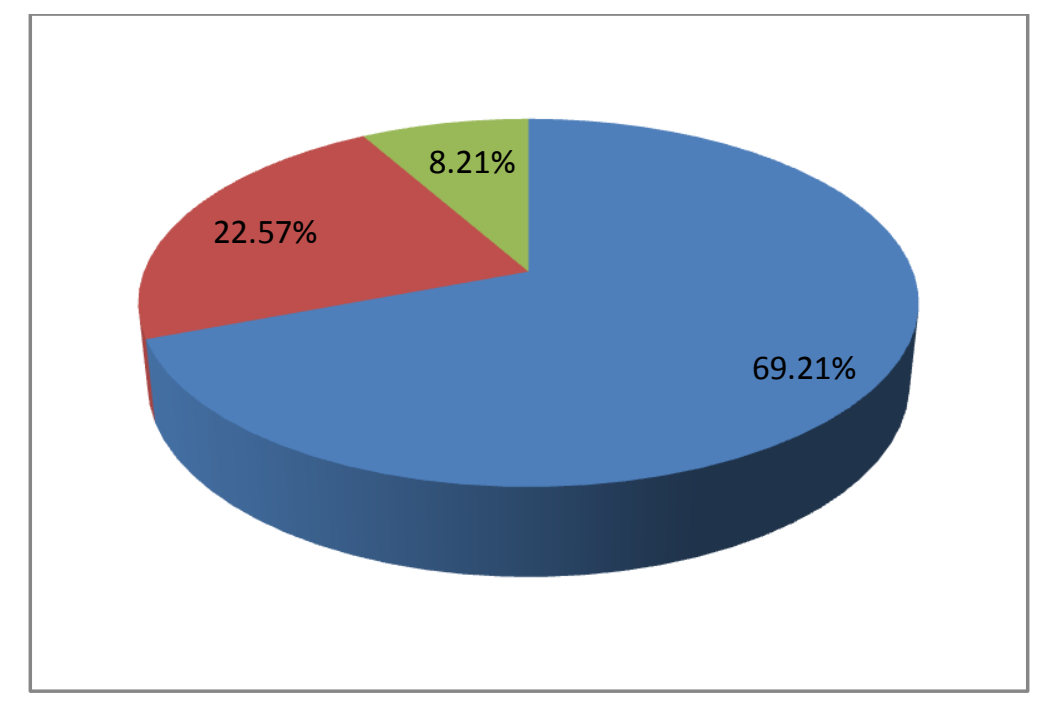

Keterangan :

: $\quad$ : Biru adalah kontribusi usaha tani.

: Orange adalah kontribusi luar uasaha tani.

: Hijau adalah kontribusi trnasportasi gerobak. 


\section{KESIMPULAN DAN SARAN}

\section{Kesimpulan}

Berdasarkan hasil penelitian dapat disimpulkan bahwa :

1. Ternak sapi sebagai alat transportasi gerobakmemberikan kontribusi yang dilihat waktu kerja ternak sapi sebesar 1.284 jam dalam periode produksi kelapa, untuk mengankut hasil kebun kelapa, kebun pisang, dan kebun pala.

2. Sarana transportasi gerobak memberikan kontribusi pendapatan sebesar Rp. 23.095.000 atau 8.21\% dari keseluruhan pendapatan petani dalam satu periode produksi kelapa.

\section{Saran}

Beradasrkan hasil penelitian dapat disarankan bahwa kebutuhan pakan untuk ternak sapi dapat ditingkatkan baik kualitas maupun kuantitasnya mengingat bahwa tenaga ternak sapi digunakan sebagai alat transportasi.

\section{DAFTAR PUSTAKA}

Ahmadi, A. H. 2003. Sosiologi Pendidikan. Penerbit PT. Rineka Cipta, Jakarta.

Abidin, A. dan Simanjutak, D. 1997. Ternak Sapi Potong. Direktorat Jenderal Peternakan, Jakarta.

Bamualim, A. Wirdahayati R.B. Boer, M. 2004. Status dan Peranan Sapi Lokal Pesisir di Sumatera Utara. Prosiding Seminar.

Dinas Pertanian dan Ketahanan Pangan Daerah Provinsi Maluku Utara, 2011. Buku Statistik Peternakan. Dinas Pertanian dan Ketahanan Pangan Daerah Provinsi Maluku Utara, Ternate.

Kairupan, A.N. 2001. Kajian Pengembangan Sapi Lokal di Kawasan Pengembangan Ekonomi Terpadu (KAPET) Batui, Provinsi Sulawesi Tengah. Disertasi. Bogor: Program Pascasarjana, Institut Pertanian Bogor. 
Kerlinger, F.N. 2004. Azas-Azas Penelitian BehavioraL. Terjemahan: Simatupang, L.R. Gadjah Mada University Pres. Yogyokarta.

Luas. N. O. 2007. Kontribusi tenaga Ternak Sapi Terhadap Pendapatan Petani Peternak di Kecamatan Langowan Timur Kabupaten Minaha. Skripsi. Fakultas Peternakan. Unsrat, Manado.

Olii, J. 2013. Kontribusi Usaha Ternak Sapi Terhadap Pendapatan Rumah Tangga Petani Di Kecamatan Kalawat Kabupaten Minahasa Utara.

Program Penyuluh Pertanian (BP3K). Kecamatan Jailolo, 2011. Deskripsi Umum Wilayah.

Soekartawi, A. Soeharjo, Dilon, J. L. Hardaker. J. B. 1986. Ilmu Usahatani dan Penelitian untuk Perkembangan Petani Kecil. UI-Pres, Jakarta.

Soekartawi, 1995. Analisa Usaha Tani. Universitas Indonesia Penerbit UI Press, Jakarta.

Syafaat, N. A. Agustian T. Pranadji M. Ariani I. Setiadjie, dan Wawan.1995. Studi Kajian SDM dalam Menunjang Pembangunan Pertanian Rakyat Terpadu di KTI. Bogor. Puslit Sosial Ekonomi Pertanian Bogor.

Suryana, 2010. Model praktis Penelitian Kuantitatif dan Kualitatif. Universitas Pendidikan Indonesia.

Suyatna, I. G. dan Antara M. 2014. Bahan Ajar Metodologi Penelitian. Dempasar. Program S2 Magister Agribisnis Universitas Udayana.

Tabel 1. Responden Petani Peternak Sapi di Kecamatan Jailolo Kabupaten Halmahera Barat

\begin{tabular}{llcc}
\hline No. & \multicolumn{1}{c}{ Desa Sampel } & Populasi Petani Peternak & Responden \\
\hline 1. & Hoku-hoku kie & 35 & 10 \\
2. & Tedeng & 45 & 10 \\
3. & Akediri & 55 & 10 \\
\hline
\end{tabular}


Tabel 2. Pendapatan Usaha Tani di Kecamatan Jailolo Kabupaten Halmahera Barat

\begin{tabular}{|c|c|c|c|}
\hline No. & Uraian & $\begin{array}{c}\text { Pendapatan } \\
\text { (Rp/Periode Produksi Kelapa) }\end{array}$ & $\begin{array}{c}\text { Persentase } \\
(\%)\end{array}$ \\
\hline 1. & Kebun kelapa & 142.800 .000 & 73.35 \\
\hline 2. & Kebun pisang & 46.080 .000 & 23.66 \\
\hline & Kebun pala & 5.800 .000 & 2.97 \\
\hline \multicolumn{2}{|c|}{ Total } & 194.680 .000 & 100,00 \\
\hline \multicolumn{2}{|c|}{ Rata-rata } & 6.489 .333 .3 & \\
\hline
\end{tabular}

Tabel 3. Kontribusi Pendapatan Transportasi Gerobak, Pendapatan Luar Usahatani, Pendapatan Usaha Tani Rp/ Periode Produksi Kelapa

\begin{tabular}{|l|l|r|r|}
\hline No. & Uraian Pendapatan & \multicolumn{1}{|c|}{$\begin{array}{c}\text { Jumlah Pendapatan } \\
\text { (Rp/Produksi Kelapa) }\end{array}$} & \multicolumn{2}{|c|}{$\begin{array}{c}\text { Persentase } \\
(\%)\end{array}$} \\
\hline 1. & Transportasi Gerobak & 23.095 .000 & 8.21 \\
\hline 2. & Luar Usaha Tani & 63.500 .000 & 22.57 \\
\hline 3. & Usaha Tani & 194.680 .000 & 69.21 \\
\hline Total & & 282.275 .000 & 100.00 \\
\hline
\end{tabular}

